\title{
Dampak Pertumbuhan Ekonomi, Manfaat Sosial Dan Biaya Sosial Terhadap Pembangunan Infrastruktur Jalan Di Kabupaten Pekalongan Propinsi Jawa Tengah (Khususnya Di Dataran Tinggi Bagian Selatan)
}

\author{
M.Guntur, Juliaman P, Wawan Darwan, Bambang Istianto \\ PTDI-STTD
}

Email: guntur3@gmail.com

\begin{abstract}
The purpose of conducting this writing is to assess and analyze the extent of the impact of economic growth, social benefits and social benefits to the construction of road infrastructure received and enjoyed by the people of Pekalongan Regency Central Java province, especially in highland areas in 5 districts (Doro, Talun, Petungkriyono, Paninggaran, Lebakbarang).By using purpose sampling technique, the sample that is targeted and focus study is the homogeneity of society as well as the livelihoods of the population. Data acquisition is done by using primary data collection and secondary data and Forum Group discussion (FGD) with descriptive analysis method and SPSS analysis.The results of the analysis concluded there were positive and significant influences from the economic growth (X1) variable social benefits (X2) as well as to the social cost (X3). On the other hand there is a positive and significant influence between the economic growth variables (X1) social benefits (X2) and the social cost (x3).
\end{abstract}

Key words: Infrastructure for road, economic growth, social benefits, and social costs.

\begin{abstract}
Abstrak
Tujuan melakukan penulisan ini adalah untuk mengkaji dan menganalisa sejauh manakah dampak pertrumbuhan ekonomi, manfaat social dan manfaat social terhadap pembangunan insfrastruktur jalan yang diterima dan dinikmati oleh masyarakat Kabupaten Pekalongan Propinsi Jawa Tengah terutama pada daerah dataran tinggi di 5 Kecamatan ( Doro, Talun, Petungkriyono, Paninggaran, Lebakbarang).Dengan menggunakn tehnik purpose sampling, maka sample yang menjadi sasaran dan focus kajian adalah homogenitas masyarakat serta mata pencaharian penduduk. Perolehan data dilakukan dengan melalui pengumpulan data primer dan data skunder serta Forum Group Diskusi (FGD) dengan metode analisis deskriptif dan analisis SPSS.Hasil analisis berkesimpulan terdapat pengaruh positif dan signifikan dari variabel Pertumbuhan ekonomi (X1) manfaat social (X2) serta terhadap biaya social (X3). Disisi lain terdapat pengaruh positif dan signifikan antara variabel pertumbuhan ekonomi (X1) manfaat social (X2) dan biaya social (x3).
\end{abstract}

Kata Kunci : Insfrastruktur jalan, pertumbuhan ekonomi , manfaat social ,dan biaya social.

\section{A. PENDAHULUAN}

Kabupaten Pekalongan terletak di Propinsi Jawa Tengah yang berbatasan dengan Kotamadya Pekalongan di Utara (Pantura), Kabupaten Pemalang di Barat, Kabupaten Batang di Timur dan Kabupaten Banjarnegara di Selatan yang membawahi 19 Kecamatan dan 283 Kelurahan (219 kelurahan terletak di dataran rendah di sebelah utara dan 66 kelurahan terletak di dataran tinggi di sebelah selatan). Ibukota Kabupaten terletak di Kajen (terletak di tengah wilayah Kabupaten) dengan luas wilayah 836,13 km2. Berjarak $25 \mathrm{~km}$ dari Kota Pekalongan. Tingkat kepadatan penduduknya adalah 1.067 jiwa/km2 jiwa. Bagian utara Kabupaten Pekalongan merupakan dataran rendah, sedang di bagian selatan adalah merupakan dataran tinggi, masingmasing sebagian pada selatan Kecamatan Karanganyar, sebagian selatan Kecamatan Doro, Kecamatan Petungkriyono, Kecamatan Talun, Kecamatan Lebakbarang, dan Kecamatan Paninggaran yang berupa pegunungan, bagian dari rangkaian dataran tinggi Dieng. Kabupaten Pekalongan berbatasan dengan Kabupaten Banjarnegara di Selatan, Kabupaten Pemalang di barat, 
Vol. 10 No. 2 (2019): Jurnal Penelitian Sekolah Tinggi Transportasi Darat

Kabupaten Batang di Timur, Kabupaten Purbalingga di selatan dan di sebelah utara adalah Kotamadya Pekalongan.

Perekonomian Kabupaten Pekalongan bagian Selatan tumbuh signifikan dikarenakan letak nya cukup strategis yakni jalur lintas Jawa Tengah Utara (Pantura) dan Jawa Tengah bagian Selatan yang bersinergi dengan Kabupaten Pekalongan bagian Utara serta Kabupaten-Kabupaten disekitarnya.Jaringan transportasi darat terletak pada jalur lintasan menuju Kota/Kabupaten Semarang, Kota/Kabupaten Tegal , Kotamadya Pekalongan, Kabupaten Batang, Kabupaten Banjarnegara, Banyumas dan bahkan hingga kota Purwokerto. Insfrastruktur jalan di Kabupaten Pekalongan bagian Selatan, relative masih dalam kategori jalan kabupaten,namun memiliki berbagai dampak diantaranya mempercepat waktu tempuh antar kecamatan dan mendorong fungsi jalan pedesaan sebagai penghasil produk-produk pertanian agrobisnis Pembangunan insfrastruktur jalan disekitar dataran tinggi antara lain berdampak membuka peluang lapangan kerja disektor informal seperti munculnya petani-petani baru aggrobisnis, usaha-usaha sarana transportasi yang mampu membuka daerah-daerah yang terisolasi, munculnya bisnis kuliner dan fasilitas pariwisata yang merupakan dampak positif.
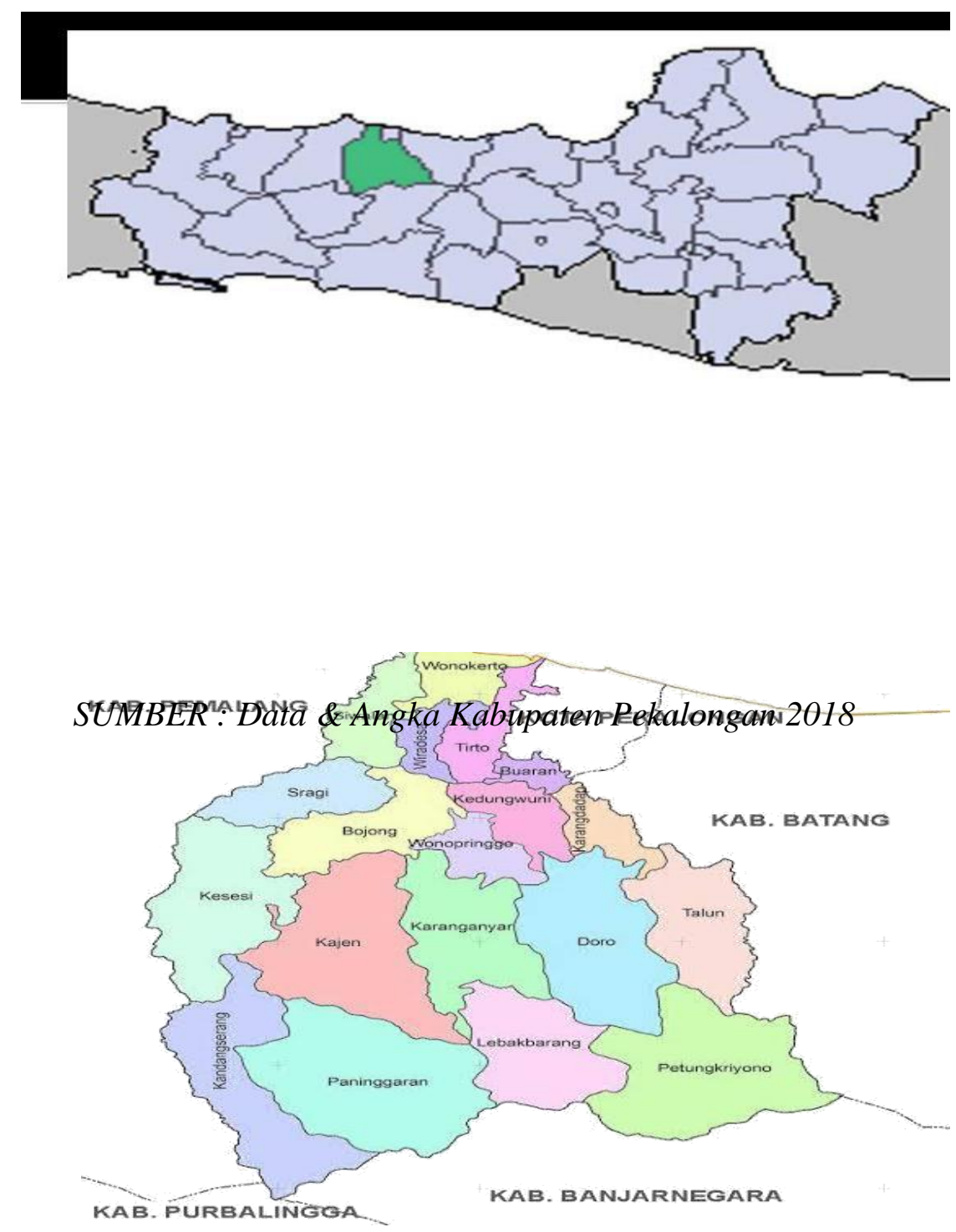


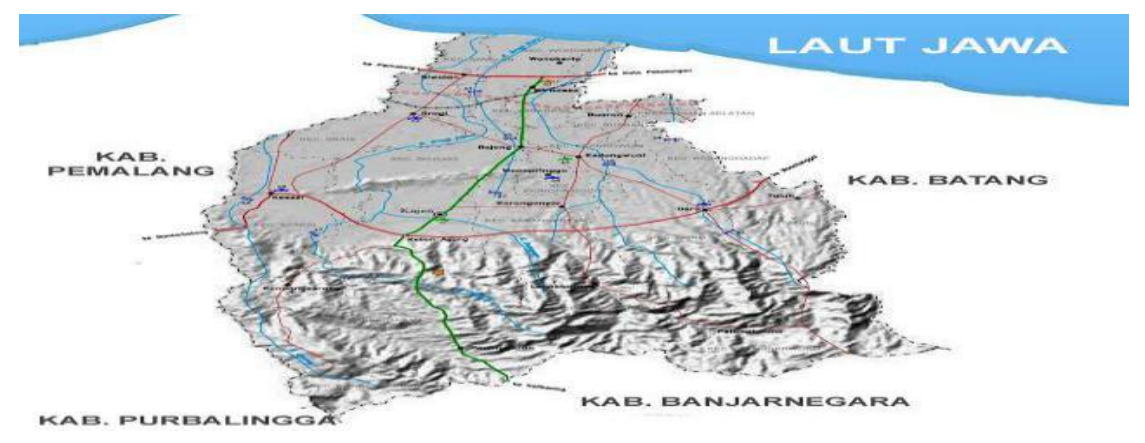

SUMBER : Data \& Angka Kabupaten Pekalongan 2018

Dampak negative pembangunan insfrastruktur antara lain adalah berkurangnya lahan produkstif pertanian, pengurangan lahan terbuka hijau serta rusaknya lingkungan hidup disekitar pembangunan insfrastruktur.Naiknya harga tanah disekitar area pembangunan insfrastruktur jalan dikarenakan munculnya investor dari kalangan pendatang (bukan penduduk asli dataran tinggi) dinilai negative dikarenakan terpinggirkannya penduduk asli yang tidak berketrampilan, sehingga berpotensi melahirkan kemiskinan baru. Berbagai upaya telah dilakukan oleh pemerintah Kabupaten Pekalongan dalam mewujudkan sarana \& prasarana baik pada area bagian Selatan maupun bagian utara. Insfrastruktur jalan yang akan diwujudkan, direnovasi dan atau aspalisasi jalan desa adalah dalam rangka pembebasan isolasi terutama pada pedesaan-pedesaan terpencil di daerah pegunungan (Kabupaten Pekalongan bagian selatan). Potensi perekonomian desa yang lebih mandiri akan terpicu dengan program-program tersebut. Masyarakat petani, pedagang, peternak akan terdorong maju karena kemudahan-kemudahan dengan tersedianya insfrastruktur jalan pedesaan yang memadai.Hal lain yang terdorong adalah meningkatnya ketrampilan (non formal) dan pengembangan (Pendidikan formal ) bagi masyarakat pedesaan yang menikmati pertumbuhan ekonominya terutama diprioritaskan bagi penduduk daerah di 5 kecamatan pegunungan yakni kecamatan Petungkriyono, kecamatan Lebakbarang, sebagian kecamatan Doro, kecamatan Karanganyar dan kecamatan Talun). Bagi pemerintah Kabupaten Pekalongan juga akan menikmati pertumbuhan PAD baik dari sector pertanian, perkebunan, pariwisata serta sector lainnya sebagai akibat tumbuhnya para pembayar pajak baru dari pedesaan. Letak geografis yang sangat unik dan indah yakni di bagian selatan berupa pegunungan merupakan area pertanian dengan produk-produk pertanian unggulan (agro-bisnis) seperti kentang, wortel, kubis, cabe, waluh, buah nangka, perkebunan karet/pinus dan bunga melati sebagai bahan baku the wangi khas produksi teh dari Pekalongan. Atas dasar latarbelakang tersebut maka peneliti akan melakukan penelitian terkait dengan "Dampak pembangunan insfrastruktur jalan terhadap pertumbuhan usahaekonomi rakyatdi Kabupaten Pekalongan Propinsi Jawa Tengah (khususnya di dataran tinggi).

\section{RUMUSAN MASALAH}

a. Bagaimana insfrastruktur jalan terwujud diarea yang mengakses menuju jalan pedesaan khususnya di dataran tinggi.

b. Sejauh manakah pertumbuhan usaha ekonomi rakyat yang berdomisili di dataran tinggi mampu berkembang dari waktu kewaktu.

c. Seperti apakah dampak insfrastruktur dan pertumbuhan ekonomi terhadap biaya social masyarakat yang berdomisili di dataran tinggi. 


\section{TUJUAN}

a. Mengetahui sejauh manakah insfrastruktur jalan terwujud diarea yang mengakses menuju jalan pedesaan khususnya di dataran tinggi.

b. Mempelajari pertumbuhan usaha ekonomi rakyat yang berdomisili di dataran tinggi mampu berkembang dari waktu kewaktu.

c. Bagaimana dampak insfrastruktur dan pertumbuhan ekonomi terhadap biaya social masyarakat yang berdomisili di dataran tinggi.

\section{B. KAJIAN PUSTAKA}

\section{PENGERTIAN INSFRASTRUKTUR \& PERTUMBUHAN EKONOMI}

Fox (2004) mendefinisikan insfrastruktur sebagai " those Services derived from the set of public work traditionally supported by the public sector to enhance private sector production and to allow for householdconsumption" Moteff (2003) mendefinisikan insfrastruktur tidak hanya terbatas pada sudut pandang ekonomi melainkan pertahanan dan keberlanjutan pemerintahan. Vooghn \& Polland (2003) menyatakan insfrastruktur secara umum meliputi jalan, jembatan dan air dan system pembuangan, bandar udara, pelabuhan, bangunan umum dan juga termasuk sekolah-sekolah, fasilitas kesehatan, penjara, rekreasi, pembangkit listrik, keamanan, pemadam kebakaran, tempat pembuangan sampah dan telekomunikasi. Jafar $\boldsymbol{M}$ (2007) menyatakan bahwa insfrastruktur memiliki peranan positif terhadap pertumbuhan ekonomi dalam jangka pendek menciptakan lapangan kerja sector konstruksi, dan pada jangka menengah/Panjang akan mendukung peningkatan efisiensi dan produktifitas sektor-sektor terkait.

\section{MANFAAT TRANSPORTASI, PEMBANGUNAN EKONOMI, MANFAAT/BIAYA SOCIAL.}

Addler (1983) menyatakan bahwa pembangunan ekonomi tidak akan pernah ideal jik tidak ada pembangunan alat transportasi, serta akan tidak produktif jika tidak ada pembaharuan pembangunan pengangkutan. Anwar (1995) menyatakan bahwa kemajuan kehidupan masyarakat akan berkorelasi sangat signifikan dengan perobahan tehnologi baru yang bertambah baik dalam transportasi dan angkutan umum.

Nasution \& M Siregar (1999) menyatakan bahwa secara social jasa transportasi sangat membantu dalam menyediakan pelayanan individu/kelompok, penyampaian informasi, serta perluasan/pemendekan jangka perjalanan. Farris \& Harding ( dalam Anwar\& Tito, 1996) menyatakan bahwa Kegiatan transportasi dapat menghasilkan manfaat social (social benefits) dan biaya social (social cost). Adanya korelasi antara pembangunan insfrastruktur transportasi, mendorong pertumbuhan ekonomi serta manfaat / biaya social .

\section{METODOLOGI PENELITIAN}

\section{Metode Analisis Data}

a. Analisis Diskriptif, yaitu menggunakan analisa non statistik untuk menganalisis data kualitatif, yaitu dengan membaca tabel-tabel, grafik / angkaangka yang tersedia kemudian dilakukan uraian dan penafsiran. Dalam hal ini data 
terlihat pada koesioner yang diisi oleh responden. Koesioner tersebut bersifat kualitatif yang kemudian dikuantitatif-kan dengan cara memberi skore (nilai) dengan menggunakan skala likert yaitu sebagai berikut : Sangat setuju diberi nilai (5), Setuju diberi nilai 4, Cukup setuju diberi nilai 3, Tidak setuju diberi nilai 2 dan Sangat tidak setuju diberi nilai 1.

b. Analisis Kuantitatif, untuk mengetahui hubungan variabel-variabel yang mempunyai hubungan, maka dilakukan pengujian hipotesis dengan perhitungan statistik. Untuk menganalisa data digunakan SPSS versi 22.00

dalam model dan pengkajian hipotesis

Pertumbuhan ekonomi di Kabupaten Pekalongan khususnya kabupaten Pekalongan bagian selatan yang meliputi 5(lima) kecamatan dataran tinggi yaitu kecamatan : Lebak barang, Peninggaran, Petung kriyono, Doro, dan Talun seetiap tahunnya mengalami peningkatan. Karakteristik pertumbuhan ekonomi dapat dilihat dari tahun 1991 sampai dengan tahun 1998 mengalami kenaikan sebesar rata-rata $2 \%$, namun pada tahun 1999 samapai dengan 2003 tidak terjadi peningkatan. Selanjutnya tahun 2004 sampai dengan 2013 mengalami peningkatan sebesar ratarata $1 \%$, peningkatan pertumbuhan ekonomi terus meningkat dari tahun 2014 sampai dengan 2018 dengan peningkatan rata sebesar $7 \%$. Seiring dengan pertumbuhan ekonomi yang meningkat setiap tahunnya maka hal ini berdampak terhadap biaya sosial yang juga meningkat setiap tahunnya dimulai tahun 1991 sampai dengan 2018. Pertumbuhan ekonomi yang meningkat pertahunnya ini mendorong bertahap mendorong perkembangan Infrastruktur.

\section{Pertumbuhan Ekonomi (X1)}

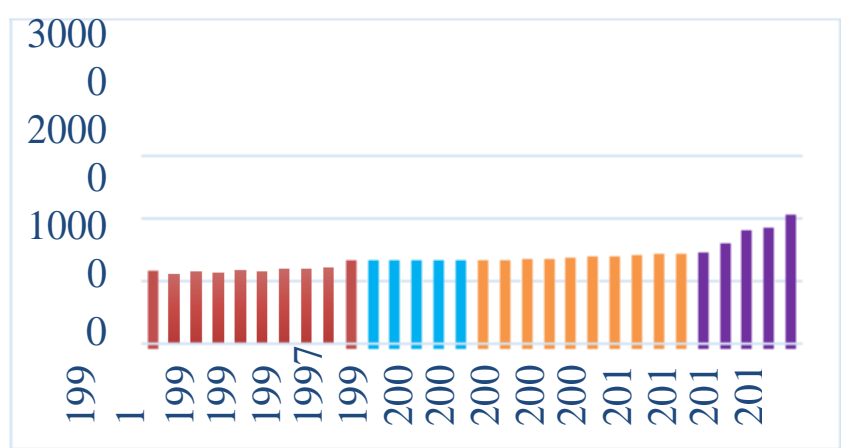

Gbr 1. Pertumbuhan Ekonomi 


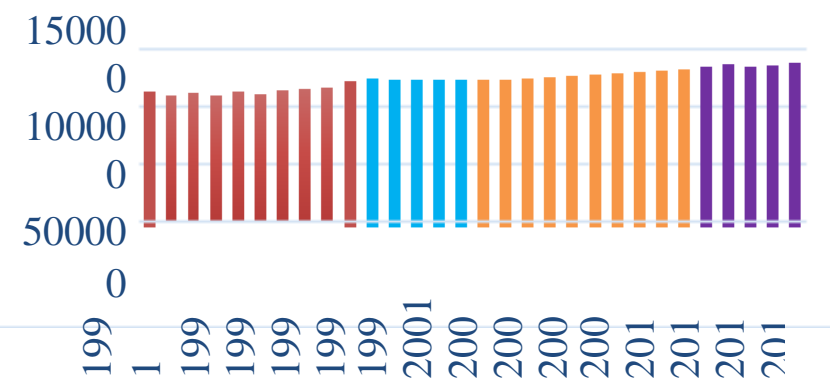

Gbr 2. Manfaat Sosial

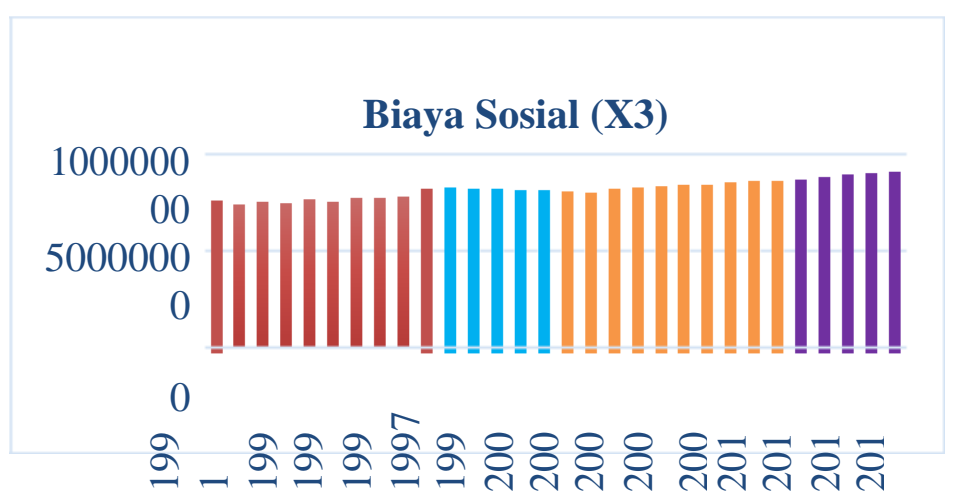

Gbr 3. Biaya Sosial

Insfrastruktur Jalan Kabupaten (Y)

1000

500

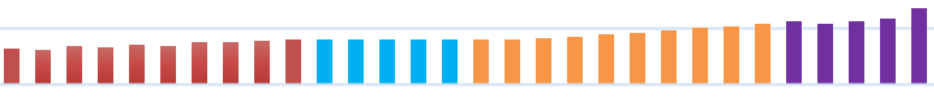

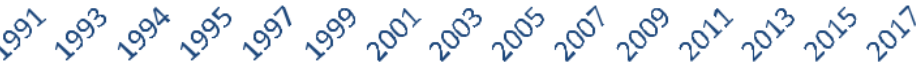
0

Gbr 4. Infrastruktur Jalan Kabupaten

D. HASIL PENELITIAN DAN PEMBAHASAN

\section{Uji Asumsi Klasik}

Pengujian dilakukan dengan tujuan untuk menghindari terjadinya penyimpangan terhadap asumsi klasik yaitu, sebagai berikut:

\section{a. Uji Normalitas}


Uji normalitas data dilakukan untuk menguji kenormalan distribusi data, dimana data yang normal atau terdistribusi secara normal akan memusat pada nilai rata-rata dan median.

Uji normalitas bertujuan untuk mengetahui seberapa besar data terdistribusi secara normal dalam variabel yang digunakan di dalam penelitian ini.

Data yang baik yang dapat dipakai dalam suatu penelitian adalah data yang telah terdistribusi secara normal.

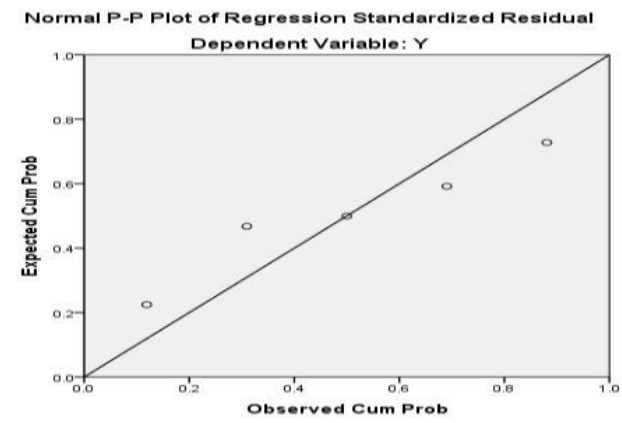

\section{Gambar 5. Uji Normalitas Data}

Berdasarkan gambar 5 di atas, menunjukkan bahwa data menyebar disekitar garis diagonal dan mengikuti arah garis diagonal atau grafik histogramnya menunjukan pola distribusi normal, dengan demikian maka model regresi mengikuti asumsi normalitas.

\section{b. Uji Multikolinearitas.}

Pengujian multikolinieritas dimaksudkan untuk menguji adanya hubungan yang kuat antara beberapa atau semua variabel independen dalam model regresi.

Jika terdapat adanya multikolinieritas maka koefisien regresi menjadi tidak menentu, tingkat kesalahanya menjadi sangat besar dan biasanya akan ditandai dengan adanya nilai koefisien determinasi yang sangat besar khususnya dalam pengujian secara simultan. Sedangkan dalam pengujian secara parsial, koefisien regresi biasanya tidak dipergunakan dan apabila dipergunakan sangat sedikit sekali koefisien regresi yang signifikan.

Pada penelitian ini, digunakan nilai VarianceInflation Factors (VIF) sebagai indikator ada atau tidaknya multikolinieritas diantara sesama variabel bebas.

Untuk menguji ada atau tidaknya pada suatu model yaitu dengan melihat nilai VIF dan nilai tolerance. Jika nilai tolerance lebih besar dari 0,1 atau nilai VIF lebih kecil dari 10, maka dapat disimpulkan tidak terjadi multikolinieritas pada data yang akan diolah. 
Tabel 2. Multikolinearitas

\begin{tabular}{|c|c|c|c|}
\hline \multicolumn{4}{|c|}{ Coefficients ${ }^{a}$} \\
\hline \multirow{2}{*}{\multicolumn{2}{|c|}{ Model }} & \multicolumn{2}{|c|}{ Collinearity Statistics } \\
\hline & & Tolerance & VIF \\
\hline \multirow[t]{3}{*}{1} & $\times 1$ & .291 & 3.437 \\
\hline & $\times 2$ & .298 & 3.355 \\
\hline & $\times 3$ & .432 & 2.317 \\
\hline
\end{tabular}

a. Dependent Variable: $Y$

Dari nilai VIF yang telah diperoleh dalam tabel di atas, menunjukkan bahwa data pada variabel bebas tidak mengandung adanya gejala korelasi yang kuat antara sesama variabel bebas, karena semua nilai VIF yang dihitung lebih kecil dari 10 dan nilai tolerance di atas 0,1 maka dapat disimpulkan tidak terdapat multikolinieritas diantara varibel bebas.

\section{c. Uji Autokorelasi}

Autokorelasi muncul karena observasi yang berurutan sepanjang waktu yang berkaitan satu sama lain. Masalah ini timbul karena residual tidak bebas dari satu observasi lainnya. Uji gejala autokorelasi yang digunakan dalam penelitian ini adalah uji DurbinWatson. Seperti yang terlihat pada tabel berikut:

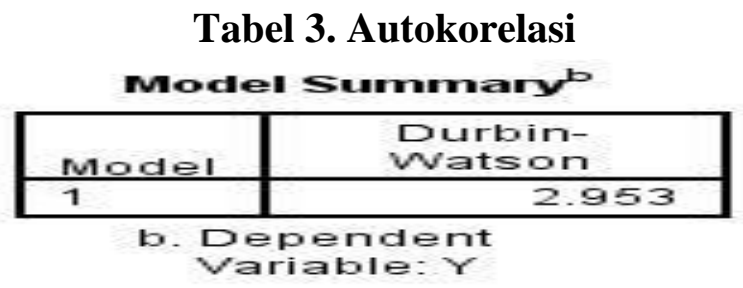

Berdasarkan tabel 2 di atas, nilai Durbin-Watson test diperoleh 2,953 dengan menggunakan derajat kepercayaan $(\alpha) 5 \%$. Karena nilai DW berada di antara -2 dan +2 , maka dapat dikatakan tidak terdapat problem autokorelasi.

\section{d. Uji Heteroskedastisitas}

Berikut adalah uji heteroskedastisitas, dimana dalam analisis regresi, varians dari residual tidak sama atau tidak memiliki pola tertentu dari satu pengamatan ke pengamatan lain, yang ditunjukkan dengan nilai yang tidak sama antara satu varians dari residual dengan besarnya varians antar residual tidak homogen, sedangkan apabila terdapat gejala varians sama disebut homokedastisitas. Hasil uji heteroskedasitas pada penelitian ini, dengan menggunakan scatterplot model, yaitu melalui diagram pencar antara nilai yang diprediksi (ZPRED) dan sudentized residual (SRESID), seperti gambar berikut: 


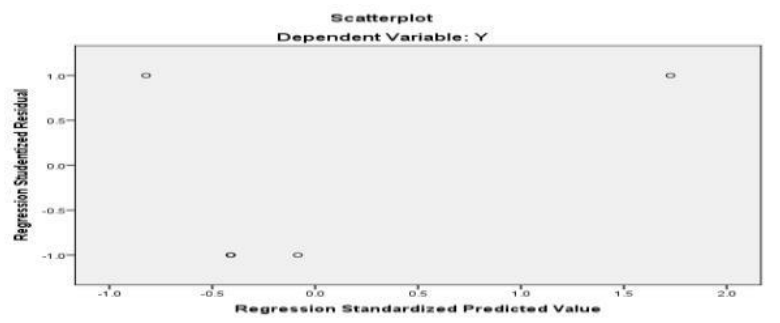

\section{Gambar 6. Uji Heteroskedasitas}

Berdasarkan diagram pencar diatas, maka dapat dilihat bahwa penyebaran residual tidak homogen. Hal tersebut dapat dilihat dari plot yang menyebar dan tidak membentuk suatu pola tertentu. Dengan hasil demikian terbukti bahwa tidak terjadi gejala homokedastis atau persamaan regresi memenuhi asumsi non-heteroskedasitas.e.

Analisis

\section{Regresi Linear Berganda}

Teknik regresi berganda ini digunakan untuk mengetahui hubungan fungsional antara variabel dependen yaitu infrastruktur jalan(Y) dihubungkan dengan dua atau lebih variabel independen yaitu pertumbuhan ekonomi (X1), Manfaat sosial (X2), dan biaya sosial (X3). Untuk mengetahui hubungan tersebut, maka perlu dilakukan uji regresi linier berganda yang dapat dilihat pada tabel berikut:

Tabel 4. Analisis Regresi Berganda

\begin{tabular}{|c|c|c|c|c|c|c|}
\hline \multicolumn{7}{|c|}{ Coefficients $^{a}$} \\
\hline & & \multicolumn{2}{|c|}{ Unstandardized Coefficients } & \multirow{2}{*}{$\begin{array}{c}\text { Standardized } \\
\text { Coefficients } \\
\text { Beta }\end{array}$} & \multirow[b]{2}{*}{$\mathrm{t}$} & \multirow[b]{2}{*}{ Sig. } \\
\hline \multicolumn{2}{|c|}{ Model } & $B$ & Std. Error & & & \\
\hline$\frac{1}{1}$ & (Constant) & 628.604 & 566.920 & & 1.109 & .467 \\
\hline & $\mathrm{x} 1$ & .006 & .001 & .288 & 7.748 & .082 \\
\hline & $\mathrm{x} 2$ & -.013 & .001 & -.776 & -21.119 & .030 \\
\hline & $\times 3$ & $1.779 \mathrm{E}-005$ & .000 & .091 & 2.982 & .206 \\
\hline
\end{tabular}

Berdasarkan hasil perhitungan SPSS 20.0 di atas maka diperoleh suatu persamaan regresi sebagai berikut :

$$
Y=628,604+0,006 X 1-0,013 X 2+0,00018 \times 3
$$

Dari persamaan tersebut dapat diinterpretasikan sebagai berikut :

a). Konstanta b0 = 628,604 menyatakan bahwa jika pertumbuhan ekonomi(X1),manfaatsosial (X2), dan biaya sosial (X3) sama dengan nol dan tidak ada perubahan, maka infrastruktur jalan (Y)sebesar 628,604 satuan.

b). Nilai koefisien regresi dari pertumbuhan ekonomi (X1) sebesar 0,006 yang artinya bahwa setiap kenaikan 1 satuan pertumbuhan ekonomi (X1), maka akan meningkatkan infrastruktur jalan(Y)sebesar 0,006 satuan.

c). Nilai koefisien regresi dari manfaat sosial (X2) sebesar -0,013 yang artinya bahwa setiap kenaikan 1 satuan manfaat sosial (X2), maka akan menurunkan infrastruktur jalan(Y)sebesar 0,013 satuan. 
d). Nilai koefisien regresi dari biaya sosial (X3) sebesar 0,00018 yang artinya bahwa setiap kenaikan 1 satuan biaya sosial (X3), maka akan meningkatkan infrastruktur jalan(Y)sebesar 0,00018 satuan.

\section{f. Koefisien Korelasi}

Analisis koefisien korelasi digunakan untuk mengetahui tingkat hubungan dua variabel, yaitu variabel bebas dan varibel tidak bebas. Tingkat hubungan antara pertumbuhan ekonomidan Manfaat sosial dengan infrastruktur jalan ditunjukkan dengan besarnya koefisien korelasi.

Tabel 5. Koefisien Korelasi

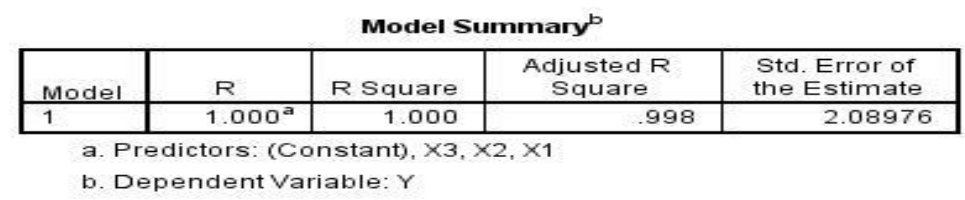

Dari tabel koefisien korelasi di atas diketahui bahwa koefisien korelasinya atau $R$ sebesar 0,998. Menggunakan pedoman menurut Sugiyono (2012: 149) bahwa nilai korelasi 0,998 berada diantara $0,80-1,00$, dengan demikian tingkat hubungan yang terjadi antara pertumbuhan ekonomi,manfaat sosial, dan biaya sosial dengan infrastruktur jalan berada dalam kategori sangat kuat dengan arah hubungan positif.

Artinya apabila pertumbuhan ekonomi,manfaat sosial, dan biaya sosialmengalami peningkatan, maka infrastruktur jalan akan meningkat juga, begitu pula sebaliknya.

\section{g. Koefisien Determinasi}

Koefisien determinasi $\left(\mathrm{R}^{2}\right)$ pada intinya mengukur seberapa jauh kemampuan model dalam menerangkan variasi variabel dependen. Besarnya kontribusi variabel pertumbuhan ekonomi,manfaat sosial dan biaya sosial terhadap infrastruktur jalan ditunjukkan dengan besarnya koefisien determinasi (adalah hasil pengkuadratan dari koefisien korelasi dikali 100\%) atau $R$ Square.

\section{Tabel 6. Koefisien Determinasi}

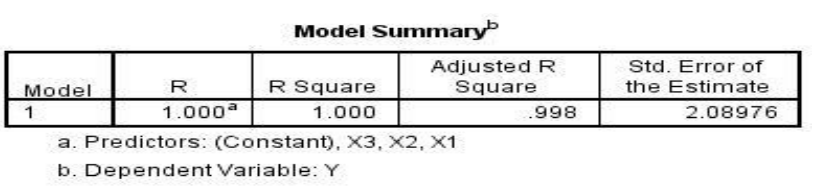

Dari tabel koefisien determinasi di atas diketahui bahwa koefisien determinasinya atau $R$ Square adalah sebesar 1,000 atau 100,0\%, artinya variabel pertumbuhan ekonomi

(X1), manfaat sosial (X2), dan biaya sosial (X3) mempunyai pengaruh terhadap infrastruktur jalan(Y) sebesar 100,0\%.

\section{h. Uji Simultan (Uji F)}

Pengujian secara simultan digunakan untuk mengetahui nilai yang memberikan kuatnya pengaruh atau hubungan antara dua variabel atau lebih secara bersama-sama. Secara simultan 
Vol. 10 No. 2 (2019): Jurnal Penelitian Sekolah Tinggi Transportasi Darat

apakah regresi berganda signifikan (nyata ataukah tidak). Dengan kata lain, akan menguji apakah regresi berganda yang telah diperoleh menunjukan bahwa pertumbuhan ekonomi (X1), manfaat sosial (X2), dan biaya sosial (X3) secara bersama-sama berpengaruh terhadap infrastruktur jalan (Y) atau tidak ada pengaruh.

Tingkat signifikansi yang digunakan dalam penelitian ini, yaitu $\alpha=0,05$.

Adapun hasil pengujian secara simultan dapat dilihat pada tabel berikut:

Tabel 7. Uji Hipotesis $\mathbf{F}$

\begin{tabular}{|c|c|c|c|c|c|c|}
\hline \multicolumn{7}{|c|}{ ANOVA $^{a}$} \\
\hline & & $\begin{array}{l}\text { Sum of } \\
\text { Squares }\end{array}$ & df & Mean Square & $\mathrm{F}$ & Sig. \\
\hline \multirow[t]{3}{*}{$\frac{\text { Mnc }}{1}$} & Regression & 10838.420 & 3 & 3612.807 & 827.282 & $.026^{b}$ \\
\hline & Residual & 4.367 & 1 & 4.367 & & \\
\hline & Total & 10842.787 & 4 & & & \\
\hline
\end{tabular}

\section{Uji Signifikansi F}

Pada tabel 5 angggotabb atas, pengujian secara simultan dengan membandingkan nilai signifikan dengan $\alpha=0,05$.

H0 diterima jika nilai signifikan $\geq \alpha=$ $0,05 \mathrm{H} 0$ ditolak jika nilai signifikan $<\alpha=$ 0,05

Dari tabel di atas, dapat disimpulkan bahwa nilai signifikan $<\alpha=0,05$ yaitu $0,026<0,05$ maka H0 ditolak.

\section{Pengambilan keputusan:}

Pertumbuhan ekonomi (X1), manfaat sosial (X2), dan biaya sosial (X3)berpengaruh signifikan secara simultan terhadap Infrastruktur jalan (Y) pada Kabupaten Pekalongan pada periode $1991-2018$.

\section{Uji Parsial (Uji t)}

Uji parsial dilakukan untuk mengetahui tingkat signifikansi pengaruh variabel independen secara parsial (individu) terhadap variabel dependen. Pengaruh pertumbuhan ekonomi,manfaat sosial, dan biaya sosial terhadap infrastruktur jalan pada Kabupaten Pekalongan pada periode 1991 - 2018 secara parsial. Menentukan tingkat signifikansi

Tingkat signifikansi yang diambil untuk penelitian ini adalah 5\%.

Untuk dapat mengetahui apakah terdapat pengaruh pertumbuhan ekonomi (X1), manfaat sosial (X2), dan biaya sosial (X3)terhadap infrastruktur jalan(Y) secara parsial, maka dilakukan pengujian hipotesis berdasarkan nilai signifikansi.

Tabel 8. Hasil Uji Hipotesis t

\begin{tabular}{|c|c|c|c|c|c|c|}
\hline \multirow{4}{*}{ http://jurnal.ptdisttc } & \multicolumn{6}{|c|}{ Coefficients $^{a}$} \\
\hline & \multirow[b]{2}{*}{ Model } & \multicolumn{2}{|c|}{ Unstandardized Coefficients } & \multirow{2}{*}{$\begin{array}{c}\text { Standardized } \\
\text { Coefficients }\end{array}$} & \multirow[b]{2}{*}{$t$} & \multirow[b]{2}{*}{ Sig. } \\
\hline & & B & Std. Error & & & \\
\hline & (Constant) & 628.604 & 566.920 & & 1.109 & .467 \\
\hline & $\times 1$ & .006 & .001 & .288 & 7.748 & .082 \\
\hline & $\times 2$ & -.013 & .001 & -.776 & -21.119 & .030 \\
\hline & $\times 3$ & 1.779E-005 & .000 & .091 & 2.982 & .206 \\
\hline
\end{tabular}


1. Pengaruh pertumbuhan ekonomi (X1) terhadap infrastruktur jalan (Y)Dari tabel 8 di atas dapat dilihat bahwa nilai signifikan $>\alpha=0,05$ yaitu $0,082>0,05$ maka H0 diterima.Dengan demikian pertumbuhan ekonomi (X1) berpengaruh signifikan terhadap infrastruktur jalan (Y) pada Kabupaten Pekalongan pada periode 1991 - 2018.

2. Pengaruh manfaat sosial (X2) terhadap infrastruktur jalan(Y)

Dari tabel 8 di atas dapat dilihat bahwa nilai signifikan $<\alpha=0,05$ yaitu $0,030<0,05$ maka

H0 ditolak. Dengan demikian manfaat sosial (X2) berpengaruh signifikan terhadap infrastruktur jalan (Y) pada Kabupaten Pekalongan pada periode 1991 - 2018.

3. Pengaruh biaya sosial (X3) terhadap infrastruktur jalan(Y)

Dari tabel 8 di atas dapat dilihat bahwa nilai signifikan $>\alpha=0,05$ yaitu 0,206 $>0,05$ maka H0 diterima. Dengan demikian biaya sosial (X2) berpengaruh signifikan terhadap infrastruktur jalan (Y) pada Kabupaten Pekalongan pada periode 1991 - 2018.

\section{E. SIMPULAN}

a. Berdasarkan hasil analisis data yang telah dilakukan terhadap seluruh data yang diperoleh, maka dapat diambil kesimpulan bahwa insfrastruktur jalan dapat terwujud diarea yang mengakses menuju jalan pedesaan khususnya di dataran tinggi dikarenakan masing-masing variabel berpengaruh signifikan pada Kabupaten Pekalongan pada periode 1991 - 2018 khususnya pada dataran tinggi.

b. Pertumbuhan usaha ekonomi rakyat yang berdomisili di dataran tinggi terus menerus mampu berkembang dari waktu kewaktu yang kemudian mendorong meningkatkan perkembangan insfrastruktur jalan yang berdampak meningkatkan pertumbuhan transportasi angkutan umum dan angkutan barang.

c. Manfaat social teraplikasi dengan terbangunya sekolah-sekolah dari tingkat dasar hingga sekolah menengah serta fasilitas kesehatan/klinik-klinik baik yang dibangun pemerintah dan swasta.

d. Dampak pertumbuhan ekonomi dan biaya sosial masyarakat yang berdomisili

didataran tinggi terhadap infrastruktur jalan sangat relevan dengan ketersediaan sarana transportasi yang efisien, tepat waktu dengan teknologi tinggi, informasi rute yg mudah ditemukan, angkutan umum yang dikelola secara terpadu seperti halnya Angkutan Barang, Angkutan Umum (Taxi, MRT, LRT, KA serta Bus) yang tarifnya diatur oleh pemerintah secara resmi termasuk jika muncul biaya tambahan, hingga syarat-syarat SDM ( sopir ) yang diseleksi secara ketat agar budaya pelayanan prima 
Vol. 10 No. 2 (2019): Jurnal Penelitian Sekolah Tinggi Transportasi Darat

semakin terwujud di daerah 5 kecamatan di area pegunungan Kabupaten Pekalongan.

\section{DAFTAR PUSTAKA}

Adler. A. 1983. Evaluasi Ekonomi Proyek-Proyek Pengangkutan. Diterjemahkan oleh Paul Sitohang. UI Press Jakarta

Anwar. A. dan Tiro. M. 1996. Sistem Transportasi Di Kawasan Metropolitan Jakarta dan Implikasinya Kepada Kes-ejahteraan Golongan Masyarakat Kech.

Jurnal Perencanaan Pembangunan Wilayah dan Perdesaan (PWD). Volme 1 No. 2: 93-123. Akhmad. 2005. Amber dan Komin, Studi Perubahan Ekonomi Di Papua, Bigraf Publishing Yogyakarta.

Firman. 2007. Dampak Sektor Transportasi Terhadap Sektor Pertanian dan Peternakan di Indonesia.Pusat Penelitian : Universitas Padjadjaran

Dercon, S., dan P. Krishnan. Changes In Poverty In Rural Ethiopia 1989-1995:Measurement, Robustness TestsAnd Decomposition. WPS/98ᄀ7. Oxford: Center for the Study of African Economics. 1998.

Fan. S., L. Zhang, dan X.Zhang. 2002. Growth, Inequality, and Poverty in Rural China : The Role of Public Investments. International Food Policy Research Institute Research Report 125. Setyari, Ni putu Wiwin. 2011 Evaluasi Dampak Kredit Mikro Terhadap Kesejahteraan Rumah Tangga di Indonesia: Analisis Data Panel. Jurnal Ekonomi Kuantitatif Terapan, Volume 5 Nomor 2 Agustus 2011: hal141-150.

Siregar. M. 1990. Beberapa MasalahEkonomi dan Manage-ment Pengangkutan. F.E. UI.

TriBastuti Purwantini dan RudiSunarja Rivai. 2008. Dampak Pembangunan

Prasarana Transportasi Terhadap Kesejahteraan Masyarakat Pedesaan: (Kasus Kabupaten Bulu Kumba Sulawesi Selatan). Jurnal, Pusat Analisis Sosial Ekonomi dan Kebijakan Pertanian, Bogor.

Kasiyanto.M.J. 1996. Masalah dan Strategi Pembangunan Indonesia. PT.Pustaka Pembangunan Swadaya Nusan $\neg$ tara Jakarta. Cetakan ke -1 Kwon, Eunkyung. 2001. (Infrastructure, Growth And Poverty Reduction In Indonesia: - ACrosssectionalAnalysisAsianDevelopment Bank Institute).

Marwan Ja'far. 2007. InfrastrukturPro Rakyat, Strategi Investasi Infrastruktur Indonesia Abad 21. Pustaka Toko Bangsa

Nasution M.S.Tr. 1994.Manajemen Transportasi. Gahlia Indonesia.

Setyari, Ni putu Wiwin. 2011.Evaluasi Dampak Kredit Mikro Terhadap Kesejahteraan Rumah Tangga di Indonesia: Analisis Data Panel. Jurnal Ekonomi Kuantitatif Terapan, Volume 5 Nomor 2 Agustus 2011: hal 141-150.

Siregar. M. 1990. Beberapa Masalah Ekonomi dan Management Pengangkutan F.E.UniversitasIndonesia. 